\title{
RADIOCARBON DETERMINATIONS FROM THE MULIFANUA LAPITA SITE, UPOLU, WESTERN SAMOA
}

\author{
Fiona J Petchey \\ Radiocarbon Dating Laboratory, School of Science and Technology, University of Waikato, Private Bag 3105, Hamilton, \\ New Zealand. Email: fpetchey@waikato.ac.nz.
}

\begin{abstract}
The Mulifanua ferry berth has the distinction of being the only site in Samoa with dentate-stamped Lapita wares, and is the most easterly Lapita site in the Pacific. Two new radiocarbon determinations of material associated with Lapita pottery found at Mulifanua are presented. The accuracy of this data is evaluated according to the results of recent reassessment of pottery from the site, and current theories regarding the age of Lapita settlement in the eastern Pacific. The resulting calibrated radiocarbon ages put occupation of the Mulifanua Lapita site at around 2880-2750 cal BP (930-800 BC). This conclusion is in agreement with the pottery chronology and supports recent hypotheses of rapid Lapita settlement in the Fiji/Tonga region around 2850-2700 cal BP (900-750 BC).
\end{abstract}

\section{INTRODUCTION}

In 1973, a number of potsherds were recovered during the construction of a new Upolu-Savai'i inter-island ferry berth and turning basin at Mulifanua, northwest Upolu, Samoa $\left(13^{\circ} 50^{\prime} \mathrm{S}, 172^{\circ} \mathrm{W}\right)$ (Figure 1). Some sherds had distinctive dentate-stamped markings typical of Lapita assemblagesone of the more distinctive components of the Lapita Cultural Complex, which stretched from the Bismarck archipelago to Samoa (around 3500 to 2000 years ago) (Green 1979). Green (1974b:1703) suggested an affinity between the Mulifanua ceramics and Lapita assemblages in the eastern Pacific, then dated to around 1300-1000 BC (i.e. Early Eastern Lapita ${ }^{1}$ ), on the basis of a high percentage of decoration (7.8\%) and similarity of motifs to sites in Fiji and Tonga. Following extensive research in Western Samoa, Green $(1974 a: 247-53 ; 1974 b: 174)$ proposed an evolutionary sequence for pottery development whereby initial Lapita colonization occurred around 700-800 BC, with a cultural transition from decorated Lapita ware to a distinct Samoan variant of Polynesian Plainware (distinguishable from the earlier Lapita assemblages by a lack of dentate-stamping with other forms of decoration restricted to rims and lips, and a diminished variety of vessel forms (Green 1974a: 253)) around $300 \mathrm{BC} . \mathrm{A}{ }^{14} \mathrm{C}$ determination of shell (NZ-1958) placed occupation at Mulifanua about 3000 years ago (Green and Richards 1975:313-4), slightly earlier, but essentially in agreement with Green's (1974b) hypothesis.

Limited analysis of the potsherds from Mulifanua compounded uncertainties not only with Green's (1974b) interpretation of the finds, but also with the ${ }^{14} \mathrm{C}$ age, the developing picture of settlement and the hypothesized ceramic chronology in Samoa. In particular, Clark $(1993,1996)$ and Clark and Michlovic (1996) pointed to the absence of Lapita sites elsewhere in Samoa as well as the presence of Polynesian Plainware sites at 'Aoa (Eastern Tutuila) and To'aga (Ofu, Manu'a Islands), the lowest layers of which give calibrated radiocarbon results that are contemporary with the Mulifanua occupation (1505-809 BC [Clark 1993] and 1401-817 BC [Kirch 1993], respectively). Clark (1993: 325; 1996:449-450), therefore, questioned the Early Eastern Lapita designation of the Mulifanua ferry berth ceramics, instead suggesting the collection consisted of pottery in which the distinctive dentate decorations were rarely applied. Accordingly, Lapita assemblages composed largely of plain pottery would be the norm as is the case at 'Aoa and To'aga. Clark (1996:450) also suggested that

\footnotetext{
${ }^{1}$ Regional ceramic chronologies of the Lapita period typically divide it into Early Eastern and Late Eastern (ca. 1000$500 \mathrm{BC}$ ) phases based on increasing loss of vessel forms and simplification in decoration which is generally restricted to vessel rims and lips (Green 1974a:253). Several researchers have found this distinction difficult to apply, however (i.e. Kirch 1988:182) (Burley et al. 1999:351-2).
} 
the decorated sherds from Mulifanua may represent trade ware brought in from outside the archipelago. He favored the view, however, that dentate-stamping was abandoned almost immediately after initial Samoan colonization, and that colonization was limited. This would isolate Samoan ceramics from the more decorative dentate-stamped components of Lapita pottery in Tonga and Fiji, as well as implying a change to Polynesian Plainware sooner than proposed by Green (1974a:247-53; 1974b:174). Recently, Dickinson and Green (1998) have demonstrated that the limited number of Samoan Lapita sites is likely to be a consequence of local subsidence rather than limited colonization. Ceramic analysis by Petchey (1995) has also confirmed Dickinson's (1974) report that temper from both the plain and dentate decorated Mulifanua sherds was derived from Samoan volcanic sources, with the exception of one sherd tentatively identified as Fijian in origin.

Dickinson and Green (1998:243-4) also reported a new radiocarbon result for Mulifanua of turtle bone which supported an occupation at around $2750 \mathrm{cal} \mathrm{BP}(800 \mathrm{BC})$. While this was closer to Green's (1974b:174) initial estimation based on decorated pottery, it was somewhat earlier than a date reported by Petchey (1995:52-4) of 2358 cal BP (409 BC) for shell from the site. The announcement of the turtle bone date coincided with a reanalysis of ${ }^{14} \mathrm{C}$ ages from Fijian and Tongan sites containing dentate-stamped pottery which indicated that the period of eastern Lapita settlement might have been quite brief (2850-2700 cal BP), but younger than previously thought (Burley et al. 1999; Anderson and Clark 1999:31). Further, Lapita colonization occurred so rapidly that no chronological gradient could be distinguished within the ${ }^{14} \mathrm{C}$ record of the Fiji-Tonga-Samoa region. Anderson and Clark (1999:37) considered this to imply either high levels of settlement mobility after colonization, or relatively large numbers of colonists and a relatively short period of time before the sequent Polynesian Plainware ceramic period began.

The chronological placement of Samoan Lapita is, therefore, important to theories of Lapita expansion and Polynesian Plainware development. This paper presents the new turtle bone ${ }^{14} \mathrm{C}$ determination mentioned by Dickinson and Green (1998:243) and discusses the reliability of all ${ }^{14} \mathrm{C}$ determinations from Mulifanua. This research was carried out as part of a larger investigation into the temper and clay, form, technology and decoration of the ceramics from Mulifanua (Petchey 1995).

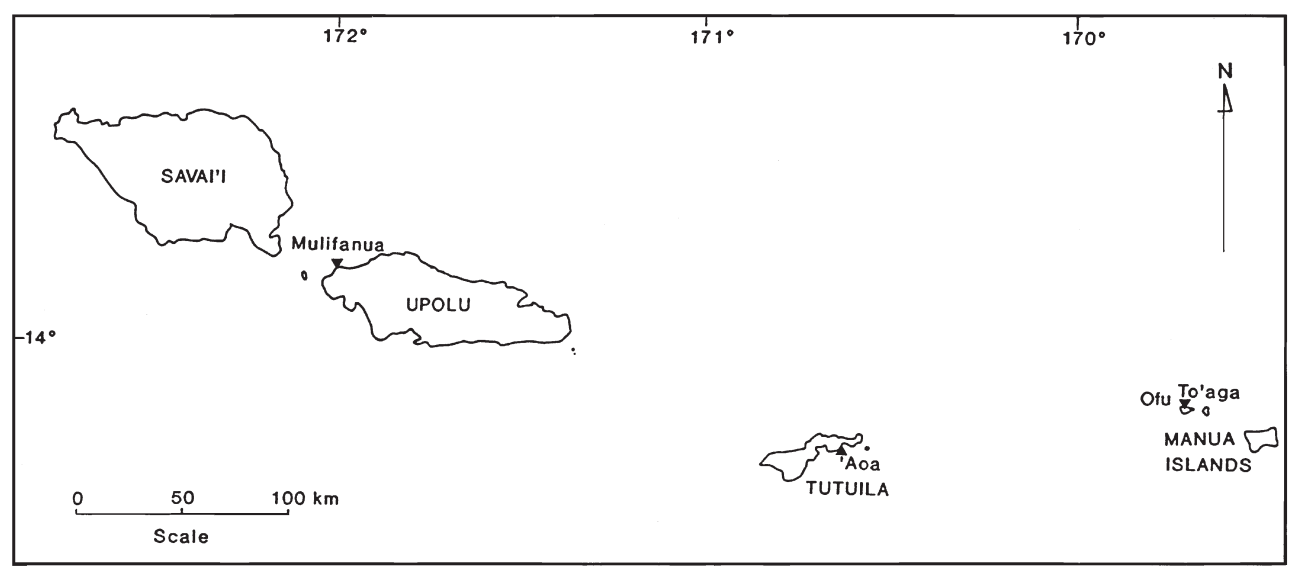

Figure 1 The Samoan Islands showing the location of Mulifanua, 'Aoa and To'aga ceramic sites 


\section{Mulifanua: The Site}

Lapita occupation at Mulifanua covered a band 30-40 m wide and at least $110 \mathrm{~m}$ long on a former coral sand beach. Two coral islets formed a shallow lagoon protecting the site from direct wave action (Leach and Green 1989:326). When discovered, however, the midden deposit was $1.5 \mathrm{~m}$ below sea level and partly encased in the base of a cemented coralline crust. The shell, sherds and bone-collected while dredging for a new ferry berth-lay within a humus rich layer on top of a sterile paleobeach sand, an average of $4.6 \mathrm{~m}$ thick, composed of basalt pebbles and coral fragments (Jennings 1974:176-7; Dickinson and Green 1998:242-3).

\section{METHOD}

A total of four ${ }^{14} \mathrm{C}$ determinations have been obtained for the Lapita occupation at Mulifanua. One ${ }^{14} \mathrm{C}$ determination (NZ-1959) was derived from the calcitic cement of the coralline capping. NZ1958 and NZA-4780, on the other hand, date shells embedded in the coralline crust and are thought to have been derived from the midden deposit. Lastly, a sample of turtle bone (NZA-5800), which was pretreated to collagen (Sample Pretreatment Form, Rafter Radiocarbon Laboratory) (see Redvers-Newton and Coote 1994 for method), lay with the sherds on top of the coral sand deposit (R Green personal communication 1999; Dickinson and Green 1998:242-3). All ${ }^{14} \mathrm{C}$ determinations were calibrated using the program OxCal v3.0 (Bronk Ramsey 1995). The shell and turtle bone collagen results were calibrated using the marine curve of Stuiver, Reimer and Braziunas (1998) with the local reservoir correction factor, or $\Delta \mathrm{R}$, set at $57 \pm 23 \mathrm{yr}$ as calculated for Upolu, Western Samoa by Phelan (1999).

\section{RESULTS}

Table 1 shows the calibrated ${ }^{14} \mathrm{C}$ results. The prefixes "NZ" and "NZA" refer to ages calculated at the Rafter Radiocarbon Laboratory, IGNS, Lower Hutt, Wellington. NZ-1959 gives a calibrated result of 190-10 BC and is considered to date the age of re-crystallization of the beach rock. This sets an upper limit for the end of the occupation (Green and Richards 1975:314) and the date is discarded from further discussion. There is, however, considerable variation between the remaining three ${ }^{14} \mathrm{C}$ determinations. NZ-1958 yields a calibrated age of $1259-828 \mathrm{BC}$ at $1 \sigma$, whereas NZA4780 puts the time of occupation between 585 and $382 \mathrm{cal} \mathrm{BC} \mathrm{(at} 1 \sigma$ ), and the turtle bone collagen yields a calibrated age at $1 \sigma$ of $888-772 \mathrm{BC}$. When these three calibrated ${ }^{14} \mathrm{C}$ determinations are evaluated using OxCal combine probabilities calculations (Bronk Ramsey 1998), the level of agreement $\left(\mathrm{A}_{\text {overall }}\right)$ falls below the calculated agreement index $(\mathrm{An})$ for these three samples (i.e. $\mathrm{A}_{\text {overall }}$ $=11.9 \%(<\mathrm{An}=40.8, \mathrm{n}=3))$, implying that no significant relation exists.

Table 1 Radiocarbon dates for Mulifanua Lapita

\begin{tabular}{llcccl}
\hline Material & Lab nr & $\delta^{13} \mathrm{C} \%$ & CRA (BP) & Cal. 68\% & Reference \\
\hline $\begin{array}{l}\text { Shell embedded in coral- } \\
\text { line crust associated with } \\
\text { sherds }\end{array}$ & NZ-1958 & +2.0 & $3251 \pm 155$ & $\begin{array}{r}3209-2778 \mathrm{BP} \\
(1259-828 \mathrm{BC})\end{array}$ & $\begin{array}{l}\text { Green and Richards (1975); } \\
\text { Leach and Green (1989) }\end{array}$ \\
$\begin{array}{l}\text { Coralline crust cement } \\
\text { Turtle bone collagen }\end{array}$ & NZ-1959 & +3.4 & $2475 \pm 63$ & $\begin{array}{c}2140-1960 \mathrm{BP} \\
(190-10 \mathrm{BC})\end{array}$ & Green and Richards (1975) \\
& NZA-5800 & -16.9 & $3062 \pm 66$ & $\begin{array}{c}2838-2722 \mathrm{BP} \\
(888-772 \mathrm{BC})\end{array}$ & New data \\
$\begin{array}{l}\text { Shell embedded in coral- } \\
\text { line crust associated with } \\
\text { sherds }\end{array}$ & NZA-4780 & +1.6 & $2788 \pm 67$ & $\begin{array}{c}2535-2332 \mathrm{BP} \\
(585-382 \mathrm{BC})\end{array}$ & Petchey (1995) \\
\hline
\end{tabular}




\section{DISCUSSION}

Despite discrepancies in the ${ }^{14} \mathrm{C}$ determinations for Mulifanua and the less than ideal contextual security of the samples, an informed assessment of the data is possible.

One possibility is that the shell samples embedded in the coralline crust (NZ-1958 and NZA-4780) were not associated with the Lapita midden, as assumed, but introduced at a later stage, possibly during the subsidence of the site when there could have been opportunity for the build-up of marine debris or erosion. Dickinson and Green (1998:242-3) have argued, however, that the extent and coherence of the site does not support the hypothesis that the sherds were scattered by currents, or eroded from an onshore site. Moreover, the deposit was located in a protected lagoon shore shielded by an offshore barrier reef and coastal fringing reef (Jennings 1974:177; Leach and Green 1989: 324-5; Dickinson and Green 1998:243), and neither shell sample had any indication of water-rolling. Even so, the possible introduction of exogenous material cannot be excluded.

Second, turtle bone determinations have not always given reproducible and acceptable results (e.g. NZ-4906 and NZ-4810 from Qaranipuqa rock shelter, Fiji (Anderson and Clark 1999:36) and AA1920 from Tongatapu (Dye 1990)) and turtle bone is essentially an untested ${ }^{14} \mathrm{C}$ sample type requiring in-depth study. Further, the Mulifanua turtle bone has not been formally identified, though green turtles (Chelonia mydas) and hawksbills (Eretmochelys imbricata) are the common turtle species in Western Samoa (Balazs 1995:247-8). Both green turtles and hawksbills are omnivorous, with a diet dominated by shallow marine organisms (Mortimer 1995:104-5). The $\delta^{13} \mathrm{C}$ value obtained for NZA-5800 is similar to that obtained for archaeological turtle bone results $(-17.9 \%$ o) reported by Dye (1990:144) for Tonga, and is also equivalent to values reported by Schoeninger and DeNiro $(1984$, table 1) for marine mammals $(-16.4$ to $-9.6 \%$ ). These animals should, therefore, be in equilibrium with surface water $\Delta^{14} \mathrm{C}$. Unfortunately, both green turtles and hawksbills are known to travel considerable distances (up to $2000 \mathrm{~km}$ ) (Meylan 1995:95-6) and it is likely that they ingest carbon from a wide range of local reservoirs (Dye 1990:144). Preliminary data suggests, however, that the $\Delta \mathrm{R}$ correction factor for the Fiji and Samoa regions are fairly uniform, and similar values are expected for Tonga (M Phelan personal communication May 1999), though localized differences in $\Delta \mathrm{R}$ have been recorded. In particular, widely differing $\Delta \mathrm{R}$ values have been measured around Upolu, Western Samoa $(57 \pm 23 \mathrm{yr})$ and the Manu'a Islands $(-230 \mathrm{yr})$ in American Samoa. The Manu'a Islands value is suspect, however, because of insecure association between the samples used to calculate the $\Delta \mathrm{R}$ (see Phelan 1999:100). Currently, the most extreme reservoir value in this region is a tentative $\Delta \mathrm{R}$ of $270 \pm 70 \mathrm{yr}$ for Tonga obtained on an open ocean marine shell (Anadara sp.) (Spennemann and Head 1998:1051). When this value is applied to NZA-5800 a calibrated age at $1 \sigma$ of 710-440 BC (2660-2390 BP) is obtained. This is around $200{ }^{14} \mathrm{C}$ years younger than the value given in Table 1, and similar to the age range calculated for the shell sample NZA-4780 when calibrated using Samoa's $\Delta R$. It is possible, however, that an average of all the $\Delta R$ values for this region could more closely model the carbon intake of marine turtles (Dye 1990:144), significantly reducing this $200 \mathrm{yr}$ difference. This is an area for further research.

In addition, bone can be an unreliable sample type that requires assessment to gauge the reliability of the sample, as well as extensive pretreatment prior to ${ }^{14} \mathrm{C}$ dating. An acid wash (hydrochloric or phosphoric acid), commonly referred to as a "collagen" pretreatment, will not remove all contamination and may leave $>15 \%$ in bone with $>20 \%$ protein remaining (Hedges and Van Klinken 1992: 284; Van Klinken and Hedges 1995:268). Because NZA-5800 is not accompanied by data pertinent to preservation state (see Petchey 1998) it is difficult to make an accurate assessment of the reliability of these determinations, though the sample produced insufficient carbon to enable the use of 
more extensive pretreatments (i.e. gelatinization), suggesting poor preservation (Sample Pretreatment Form, Rafter Radiocarbon Laboratory).

From knowledge of Lapita ceramic assemblages elsewhere, the calibrated date of 585-382 BC for NZA-4780 is much later than expected (Clark et al. 1997:81). The remaining dates, NZA-5800 and NZ-1958, overlap at $1 \sigma$ and have an overall agreement index of $91.4 \%(<\mathrm{An}=50.0 \%, \mathrm{n}=2)$ giving a combined date of 2880-2750 cal BP (930-800 BC). Such a date for occupation at Mulifanua is compatible with re-evaluation of radiocarbon dates from Fiji (Anderson and Clark 1999) and Tonga (Burley et al. 1999). It is also supported by analysis of the form and decoration of 5048 sherds by Petchey (1995), which confirmed Baquie (1975:3) and Green's (1974b) identification of complex rectilinear designs typical of earlier Lapita wares in Fiji and Tonga. The presence of one pottery sherd with temper probably of Fijian origin supports direct contact with that region.

\section{CONCLUSION}

Of a total of four ${ }^{14} \mathrm{C}$ determinations obtained from Mulifanua, one (NZ-1959) is considered to date a later re-crystallization event and is discarded. NZA-4780 is too late, given the high percentage of decoration on the sherds and complex decoration motifs encountered, and is likely to have been introduced into the midden deposit at a later date. Although this imposes obvious contextual problems on the remaining shell determination (NZ-1958), NZ-1958 is closer to the expected Lapita ceramic chronology. The fourth result, a sample of turtle bone (NZA-5800), is of questionable preservation state and the $\Delta \mathrm{R}$ correction used may not be applicable, though the resultant ${ }^{14} \mathrm{C}$ age is also in keeping with the ceramic chronology. Despite various problems, the data suggest that settlement of Mulifanua occurred around 2800 years ago, a conclusion that supports the hypothesis of rapid colonization within the eastern Pacific (Burley et al. 1999; Anderson and Clark 1999).

\section{ACKNOWLEDGMENTS}

I wish to express my gratitude to Prof Roger Green, Dr Peter Sheppard (Department of Anthropology, University of Auckland), Dr Rodger Sparks (Rafter Radiocarbon Laboratory, Wellington), Matthew Phelan (Radiocarbon Dating Laboratory, University of Waikato) and the staff of the Auckland Institute and Museum for advice and assistance during this research. Dr Tom Higham (Radiocarbon Dating Laboratory, University of Waikato) and Prof Roger Green commented on draft copies of this paper. I would especially like to thank Prof William Dickinson for refereed comments. This research was funded by the Green Foundation for Polynesian Research 1995.

\section{REFERENCES}

Anderson A, Clark G. 1999. The age of Lapita settlement in Fiji. Archaeology in Oceania 34:31-9.

Balazs GH. 1995. Status of sea turtles in the Central Pacific Ocean. In: Bjorndal KA, editor. Biology and conservation of sea turtles. Revised edition. Washington DC: Smithsonian Inst. Press. p 243-52.

Baquie B. 1975. Report on Mulifanua Lagoon Pottery, Upolu. Unpublished paper. Department of Anthropology, University of Auckland.

Bronk Ramsey C. 1995. Radiocarbon calibration and analysis of stratigraphy: the OxCal program. Radiocarbon 37(2):425-30.

Bronk Ramsey C. 1998. OxCal program v3.0. Oxford Radiocarbon Accelerator Unit.

Burley DV, Nelson ED, Shutler R Jr. 1999. A radiocarbon chronology for the Eastern Lapita frontier in Tonga. Archaeology in Oceania 34(2):59-70.

Clark JT. 1993. Radiocarbon dates from American Samoa. Radiocarbon 35(2):323-30.

Clark JT. 1996. Samoan prehistory in review. In: Davidson J, Irwin G, Leach F, Pawley A, Brown D, editors. Oceanic culture history: essays in honour of Roger Green. Special publication. Dunedin: New Zealand Journal of Archaeology. p 443-60.

Clark JT, Michlovic MG. 1996. An early settlement in the Polynesian homeland: excavations at 'Aoa Valley, Tutuila Island, American Samoa. Journal of Field Archaeology 23:151-67.

Clark JT, Wright E, Herdrich DJ. 1997. Interactions within and beyond the Samoan archipelago: Evidence 
from basaltic rock geochemistry. In: Weisler MI, editor. Prehistoric long-distance interaction in Oceania: an interdisciplinary approach. New Zealand Archaeological Association Monograph 21. p 68-84.

Dickinson WR. 1974. Temper sands in sherds from Mulifanua and comparison with similar tempers at Vailele and Sasoa'a (Falefa). In: Green RC, Davidson JM, editors. Archaeology in Western Samoa, Volume II. Bulletin of the Auckland Institute and Museum 7:179-80.

Dickinson WR, Green RC. 1998. Geoarchaeological context of Holocene subsidence at the Ferry Berth Lapita Site, Mulifanua, Upolu, Samoa. Geoarchaeology: An International Journal 13(3):239-63.

Dye TS. 1990. Marine turtle bones from an archaeological site in Polynesia yield reliable age determinations. Radiocarbon 32(2):143-7.

Green RC. 1974a. A review of portable artefacts from Western Samoa. In: Green RC, Davidson JM, editors. Archaeology in Western Samoa, Volume II. Bulletin of the Auckland Institute and Museum 7:245-75.

Green RC. 1974b. Pottery from the lagoon at Mulifanua, Upolu. In: Green RC, Davidson JM, editors. Archaeology in Western Samoa, Volume II. Bulletin of the Auckland Institute and Museum 7:170-5.

Green RC. 1979. Lapita. In: Jennings JD, editor. The prehistory of Polynesia. Cambridge: Harvard University Press. p 27-60.

Green RC, Richards HG. 1975. Lapita pottery and a lower sea level in Western Samoa. Pacific Science 29(4):309-15.

Hedges REM, Van Klinken GJ. 1992. A review of current approaches in the pretreatment of bone for radiocarbon dating by AMS. Radiocarbon 34(3):279-91.

Jennings JD. 1974. The Ferry Berth site, Mulifanua district, Upolu. In: Green RC, Davidson JM, editors. Archaeology in Western Samoa, Volume II. Bulletin of the Auckland Institute and Museum 7:176-8.

Kirch PV. 1988. Niuatoputapu: the prehistory of a Polynesian chiefdom. Seattle: Thomas Burke Memorial Washington State Museum. Monograph 5.

Kirch PV. 1993. Radiocarbon chronology of the To'aga site. In: Kirch PV, Hunt TL, editors. The To'aga site: three millennia of Polynesian occupation in the Manu'a Islands, American Samoa. Contributions of the University of California Archaeological Research Facility No. 51. Berkeley: University of California. p 85-92.

Leach HM, Green RC. 1989. New information for the Ferry Berth site, Mulifanua, Western Samoa. Journal of the Polynesian Society 98:319-29.

Meylan A. 1995. Sea turtle migration - evidence from Tag returns. In: Bjorndal KA, editor. Biology and conservation of sea turtles. Revised edition. Washington DC: Smithsonian Inst. Press. p 91-100.

Mortimer JA. 1995. Feeding ecology of sea turtles. In: Bjorndal KA, editor. Biology and conservation of sea turtles. Revised edition. Washington DC: Smithsonian Inst. Press. p 103-9.

Petchey FJ. 1995. The Archaeology of Kudon: Archaeological Analysis of Lapita Ceramics from Mulifanua, Samoa and Sigatoka, Fiji. Unpublished MA thesis. Department of Anthropology, University of Auckland.

Petchey FJ. 1998. Radiocarbon Analysis of a Novel Bone Sample Type: Snapper and Barracouta Bone from New Zealand Archaeological Sites. Unpublished D.Phil thesis, Department of Chemistry, University of Waikato.

Phelan MB. 1999. A $\Delta$ R correction value for Samoa from known-age marine shells. Radiocarbon 41(1):99101.

Redvers-Newton NA. Coote GE. 1994. Bone pretreatments for radiocarbon dating: A study incorporating AMS dating and ion beam analysis. Nuclear Instruments and Methods B29:270-3.

Schoeninger MJ, DeNiro MJ. 1984. Nitrogen and carbon isotopic composition of bone collagen from marine and terrestrial animals. Geochimica et Cosmochimica Acta 48:625-39.

Spennemann DHR, Head MJ. 1998. Tongan pottery chronology, ${ }^{14} \mathrm{C}$ dates and the hardwater effect. Quaternary Geochronology 17:1047-56.

Stuiver M, Reimer PJ, Braziunas S. 1998. High precision radiocarbon age calibration for terrestrial and marine sa mples. Radiocarbon 40(3):1127-51.

Van Klinken GJ, Hedges REM. 1995. Experiments on collagen-humic interactions: speed of humic uptake, and effects of diverse chemical treatments. Journal of Archaeological Science 22:263-70. 